The Geneva Papers on Risk and Insurance, 18 (No. 69, October 1993), 323-343

\title{
Private Insurance and Social Insurance Sectors in Latin America
}

\author{
Global actions, overview, and potential interaction \\ by Rony Castro de Oliveira Lyrio*
}

\section{Introduction}

An extensive analysis of the private insurance sector should put it within the overall process of socio-economic development of its region of insertion.

Besides, the overall behaviour of the activities related to social insurance should also be assessed, since the latter will be able to represent an extremely important market for the interaction and expansion of private insurance - in the present international scenery.

Thus, this analysis of the private insurance sector in Latin America seeks to confront it with the classical macroeconomic parameters and with the social insurance behaviour.

As a matter of fact, in developing countries private insurance and social insurance are very likely - and increasingly - to be analysed in a conjugate manner, in the framework of conjunctural and sectorial studies.

To our thinking, the Latin American private insurance sector in the 1990s may attain a remarkable evolution, thereby contributing significantly to the social and economic development of the region.

\section{A new global moment for Latin America}

During the 1980s, Latin America faced a period which has been generally considered as the Lost Decade, in which economic indicators stagnated (or got into retraction) and social problems grew larger and larger. This mediocre performance forms a strong contrast with the vigorous development reached by the previous decade.

A number of very representative and expressive segments of several Latin American countries are examining - and trying to understand - the Lost Decade and its perverse consequences. There is a clear awareness of the fact that such a frustration cannot come again and that new global sectorial courses must be identified, traced and converted into a new reality, more economically efficient and more socially fair.

By means of selected economic indicators, Table 1 makes possible to visualize quite clearly the presence of the so-called lost decade.

\footnotetext{
* President, Sul América Seguros, Rio de Janeiro, Brazil.
} 
Table 1:

Gross domestic product in Latin America, 1960-1991

(percentages)

\begin{tabular}{|c|c|c|c|c|c|c|c|c|c|c|}
\hline \multirow{3}{*}{ COUNTRIES } & \multicolumn{6}{|c|}{ Proportion of Regional GDP } & \multicolumn{4}{|c|}{ Real Growth Rates } \\
\hline & \multicolumn{3}{|c|}{ Averages } & \multicolumn{3}{|c|}{ Annual Averages } & \multicolumn{4}{|c|}{ Annual } \\
\hline & $\begin{array}{l}1970 \\
1979\end{array}$ & $\begin{array}{l}1980 \\
1989\end{array}$ & $\begin{array}{l}1990 \\
1991\end{array}$ & $\begin{array}{l}1960 \\
1969\end{array}$ & $\begin{array}{l}1970 \\
1979\end{array}$ & $\begin{array}{l}1980 \\
1987\end{array}$ & 1988 & 1989 & 1990 & $1991 p$ \\
\hline Argentina & 15.2 & 11.4 & 10.1 & 4.2 & 2.7 & -0.4 & -2.6 & -4.5 & 0.4 & 0.0 \\
\hline Bahamas & 0.3 & 0.3 & 0.3 & 0.0 & 2.7 & 3.3 & 2.3 & 2.0 & 1.0 & -2.0 \\
\hline Barbados & 0.2 & 0.2 & 0.2 & 5.8 & 1.5 & 0.6 & 3.5 & 3.5 & -3.7 & -3.8 \\
\hline Bolivia & 1.0 & 0.8 & 0.8 & 5.1 & 4.5 & -1.4 & 3.0 & 2.8 & 2.6 & 4.1 \\
\hline Brazil & 33.3 & 37.8 & 38.2 & 5.8 & 8.6 & 2.4 & -0.1 & 3.3 & -4.0 & 1.2 \\
\hline Chile & 3.6 & 3.3 & 3.9 & 4.5 & 2. & 1.1 & 7.4 & 10.0 & 2.1 & 6.0 \\
\hline Colombia & 4.4 & 4.8 & 5.4 & 5.2 & 5 & 3.2 & 4.1 & 3.4 & 4.1 & 2.2 \\
\hline Costa Rica & 0.5 & 0.5 & 0.6 & 5.8 & 6.2 & 1.6 & 3.4 & 5.6 & 3.7 & 1.0 \\
\hline Dominican Republic & 0.5 & 0.6 & 0.6 & 4.5 & 7.0 & 2.7 & 0.7 & 4.1 & -5.3 & -0.7 \\
\hline Ecuador & 1.3 & 1.5 & 1.5 & 4.7 & 9.4 & 1.1 & 10.5 & 0.6 & 2.3 & 2.9 \\
\hline El Salvador & 1.0 & 0.6 & 0.6 & 5.9 & 4.6 & -0.9 & 1.6 & 1.1 & 3.4 & 3.5 \\
\hline Guatemala & 1.0 & 0.9 & 1.0 & 5.5 & 5. & -0.3 & 3.9 & 3.9 & 3.1 & 3.2 \\
\hline Guyana & 0.1 & 0.1 & 0.0 & 3.4 & 1.2 & -2.4 & -3.0 & -5.6 & -2.8 & 6.7 \\
\hline Haiti & 0.2 & 0.2 & 0.2 & 0.8 & 4.5 & -0.6 & -1.5 & -1.5 & -3.0 & -4.0 \\
\hline Honduras & 0.4 & 0.4 & 0.5 & 5.7 & 5.8 & 2.2 & 4.6 & 4.3 & 0.1 & 2.2 \\
\hline Jamaica & 0.6 & 0.4 & 0.4 & 4.7 & -0.2 & 1.2 & 1.5 & 4.5 & 3.8 & 0.5 \\
\hline Mexico & 18.9 & 20.9 & 21.4 & 7.0 & 6. & 1.1 & 1.2 & 3.3 & 4.4 & 3.6 \\
\hline Nicaragua & 0.5 & 0.3 & 0.2 & 7.5 & -0.1 & 0.2 & -13.4 & -5.1 & 1.0 & -0.7 \\
\hline Panama & 0.6 & 0.6 & 0.6 & 8.0 & 4.5 & 2.8 & -15.6 & -0.4 & 4.6 & 9.3 \\
\hline Paraguay & 0.5 & 0.7 & 0.8 & 4.7 & 8.5 & 2.2 & 6.4 & 5.8 & 3.1 & 2.5 \\
\hline Peru & 4.8 & 4.1 & 3.4 & 5.2 & 3.7 & 2.2 & -8.3 & -11.6 & -4.9 & 2.2 \\
\hline Suriname & 0.2 & 0.2 & 0.2 & 5.8 & 5.6 & -1.2 & 2.2 & 1.5 & 0.4 & -2.5 \\
\hline Trinidad and Tobago & 0.8 & 0.8 & 0.6 & 5.0 & 5.3 & -3.3 & -3.8 & -2.2 & 0.5 & 2.0 \\
\hline Uruguay & 1.1 & 1.0 & 1.0 & 1.2 & 2.7 & 0.4 & 0.0 & 0.5 & 0.9 & 1.9 \\
\hline Venezuela & 9.0 & 7.6 & 7.8 & 5.9 & 4.8 & 0.6 & 6.2 & -7.8 & 5.7 & 9.2 \\
\hline Latin America & 100.0 & 100.0 & 100.0 & 5.5 & 5.9 & 1.3 & 0.5 & 1.0 & -0.1 & 3.2 \\
\hline Subregion $1^{\mathrm{a}}$ & 22.8 & 24.3 & 24.8 & 7.0 & 6.2 & 0.9 & 0.9 & 3.4 & 4.4 & 3.6 \\
\hline Subregion $2^{b}$ & 3.1 & 2.6 & 2.4 & 4.3 & 3.5 & -0.1 & -0.2 & 1.9 & -1.3 & -0.2 \\
\hline Subregion $3 c$ & 23.9 & 22.1 & 22.8 & 5.3 & 4.6 & 1.5 & 2.9 & -2.9 & 2.3 & 5.6 \\
\hline Subregion $4^{\mathrm{d}}$ & 50.2 & 50.9 & 50.1 & 5.1 & 6.6 & 1.5 & -0.6 & 1.6 & -3.1 & 2.1 \\
\hline
\end{tabular}

Source: IDB, based on official statistics of member countries. Details do not necessarily add to totals because of rounding.

a Subregion 1: Costa Rica, El Salvador, Guatemala, Honduras, Mexico, Nicaragua, and Panama.

'Subregion 2: Bahamas, Barbados, Dominican Republic, Guyana, Haiti, Jamaica, Suriname, and Trinidad and Tobago

'Subregion 3: Bolivia, Chile, Colombia, Ecuador, Peru, and Venezuela.

'Subregion 4: Argentina, Brazil, Paraguay, and Uruguay.

Source: Economic and Social Progress in Latin America 1992 Report. 
There is a pressing and increasing need for the region to re-emphasize today, in a global manner, its actions towards a process pledged to economical and social modernity, either in the way of procedures, products or managements methods.

A permanent modernization must be undoubtedly associated with the most recent, remarkable performances, such as those of Japan, Korea and the Asian Tigers, among others. The explosion of China's (very recent) and Turkey's development, as well as Germany's consistent performance are relevant examples of the urgent necessity of redirecting the Nations - incontestably - towards the routes compromised with business modernity, with a new sectorial, regional and national management. The non-orientation towards this alternative would be a case of concern, for it would indicate a noticeable propension to stagnation, and even an economic and social macro-involution.

It seems clear that the possibilities of survival for the non-efficient management of "social challenges" and "economical challenges" are minimal. The populations - and why not, the societies themselves - are loosing their patience with the inertia of obsolete models which are proving to be actually incompetent to overcome most of strategical challenges.

At this historical moment, it is possible to state that Latin America is rethinking, reanalysing and redimensioning ways and actions to face its crucial problems. Some of its countries have already brought to viability long-reaching economic and social start-ups and points of departure, thus breaking up with taboos and anachronic models of the past. That is the case of Argentina, Chile and Mexico, for instance. In many fields and sectors these countries are modernizing. One cannot asseverate the existence of new global postures already crystallized, but it is possible to point out the implantation of an underlying process of changes in the Continent - in an evident, objective and self-sustained way.

One can also note the emergence of a certain tendency to the aggregation intercountries - which reconfigures the adherence of the Continent's politics to a new operational basis. It is outstanding, in this particular subject, the case of MERCOSUL - the economical block of nations joining Argentina, Brazil, Paraguay and Uruguay - which is opening a long way towards the economic integration at the South. One good example of this new attitude is the engagement of Mexico in NAFTA.

The ideology of the search for economic and social efficiency is getting prominence and a growing importance in the Round Tables, anticipating - or overlapping - the politicalinstitutional stereotypes that impair every process of global action. Thus, the intention is to preclude the "working immobilism" of vital sectors (or areas) in several Latin American countries. An important series of debates now permeates the society, overflowing to the legislative power and even the executive. Obviously these attitudes can be thought of as still unfit to face the the Continent's difficulties. Nevertheless, they certainly represent a consistent sign of a new age.

There is a suspicion that Latin America presents a sharp trend toward what we could call a GLOBAL MEGAISOTROPY, that is, an identity of points of view in certain nodal questions. In this context, a progressive reconfiguration in some particular segment of action, putting together a number of countries, can be translated into a meaningful probability of - via the demonstration effect - influencing other nations of the Continent, either as a catalyst or as an effective agent of changes. 


\section{An overview of Latin America's economic development - evolution and present situation}

Latin America's economy in 1965 accounted for approximately $5.0 \%$ ( $\$ 102.5$ billion) of world GDP ( $\$ 2,040.0$ billion).

In 1990 this percentage was $4.6 \%$ ( $\$ 1.015$ billion vs. $\$ 22,298$ billion). It means that the relative positioning of Latin America in the World Scenery did not change significantly in 1965-1990 - despite of all the economical reordination processes throughout the world along this 25 year period.

Latin America and the Caribbean had already reached intermediate levels of economic development, in the world scenery, between the highly industrialized economies and the other developing countries.

However, one can note that the performance of economic development in Latin America had a significant decline in the 1980 s, relative to previous decades. If the region as a whole, from 1965 to 1980 , grew at a rate of $6.0 \%$ a year, from 1980 to 1990 the rythm of its development became $73 \%$ lower, dropping to $1.6 \%$ a year.

Several factors have been commonly mentioned in view of interpreting this declining performance which, by the way, had also occurred in other world's areas in the $1980 \mathrm{~s}$, as we can see at Table 2. Let us recall the high inflation rates found in Latin American countries, as well as their exposure to political convulsions and the resulting regimes of exception, their closed economies, non-integrated in the world technological development, and last but not least, the burden of their external debt incurred in the 1970s and first years of the 1980 s - all within a framework of multiple difficulties.

Table 2:

Growth of $G D P$

(Annual rates)

\begin{tabular}{|l|c|c|}
\hline COUNTRY BLOCKS & $1965-80$ & $1980-90$ \\
\hline Latin America and the Caribbean & 6.0 & 1.6 \\
\hline High-Income Economies & 3.7 & 3.1 \\
\hline South Asia & 3.6 & 5.2 \\
\hline Pacific and East Asia & 7.3 & 7.8 \\
\hline Subsaharian Africa & 4.2 & 2.1 \\
\hline Middle East and North Africa & 6.7 & 0.5 \\
\hline Low- and Medium Income Economies & 5.9 & 3.2 \\
\hline All economies & 4.0 & 3.2 \\
\hline Oil Exporters & 6.6 & 0.8 \\
\hline
\end{tabular}

Source: World Bank 
The decline of Latin America's economic above mentioned growth rate contrasts with the performances of the more developed economies which had a small reduction in their growth rates (from $3.7 \%$ to $3.1 \%$ annually), and with the performances of Asian countries, particularly those of South Asia (growing from $3.6 \%$ to $5.2 \%$ a year).

In spite of the $1980 \mathrm{~s}$, Latin America had a growth superior to the average in the 25 years between 1965 and 1990 (4.2\% a year for Latin America against 3.7\% a year for the world economy).

By analysing individually Latin America's countries, one can find out a range of different performances in the last two decades.

In the scenery described here, the growth rates of Chile, Colombia, Costa Rica, Honduras, Jamaica and Paraguay have been remarkable, for these countries more than doubled Latin America's overall rate during $1981-1990$, which averaged $1.1 \%$, as follows:

$\begin{array}{ll}\text { Colombia: } & +3.5 \% / \text { year } \\ \text { Paraguay: } & +3.1 \% / \text { year } \\ \text { Bahamas: } & +2.8 \% / \text { year } \\ \text { Chile: } & +2.6 \% / \text { year } \\ \text { Honduras: } & +2.4 \% / \text { year } \\ \text { Costa Rica: } & +2.3 \% / \text { year } \\ \text { Jamaica: } & +2.2 \% / \text { year }\end{array}$

At the opposite extreme, that of the negative performances, are Guyana $(-3.3 \%$ a year), Trinidad and Tobago ( $-3.1 \%$ a year) and Nicaragua $(-2.0 \%$ a year).

The last years of the series observed (1990/91) shows an expressive recovering in the economic annual growth rates of Guyana $(8.9 \%)$, Panama $(8.4 \%)$, Chile and Argentina $(6.0 \%)$, Bolivia (4.5\%) and Mexico (3.7\%).

\section{Population and per capita domestic product / basic evolution}

The region comprehending Latin America and the Caribbean sheltered in 1990 about 425 million inhabitants, accounting for 8 percent of world population in the same year.

The growth of the region's population has been evolving in a slightly decreasing pace, in accordance with data below:

$$
\begin{array}{ll}
1971-1980: & +2.4 \% / \text { year } \\
1981-1990: & +2.2 \% / \text { year } \\
1990-1991: & +2.0 \% / \text { year }
\end{array}
$$

In 1980, approximately 65 percent of the region's population were located in urban areas; in 1991 this cypher evolved to 72 percent. The growth rate of urban population, however, have showed declining trends; from $\mathrm{a}+3.8 \%$ a year in $1971-80$ to $\mathrm{a}+3.2 \%$ year in $1981-90$ and $\mathrm{a}+2.8 \%$ /year in $1990 / 91$.

The inadequacy of income in Latin America and the Caribbean may be well illustrated by the fact that, although with a population of nearly $8 \%$ of the world one, the region's product generation reaches only $4.6 \%$ of the Global Product of Humanity. Hence, the levels of Product per Inhabitant are still modest in the world scenery; in 1991 it ranged from a minimum level of $\$ 246$ (Haiti) to a maximum of $\$ 10,025$ (Bahamas). Table 3 illustrates the evolution of Per Capita Gross Domestic Product in Latin America and the Caribbean, 


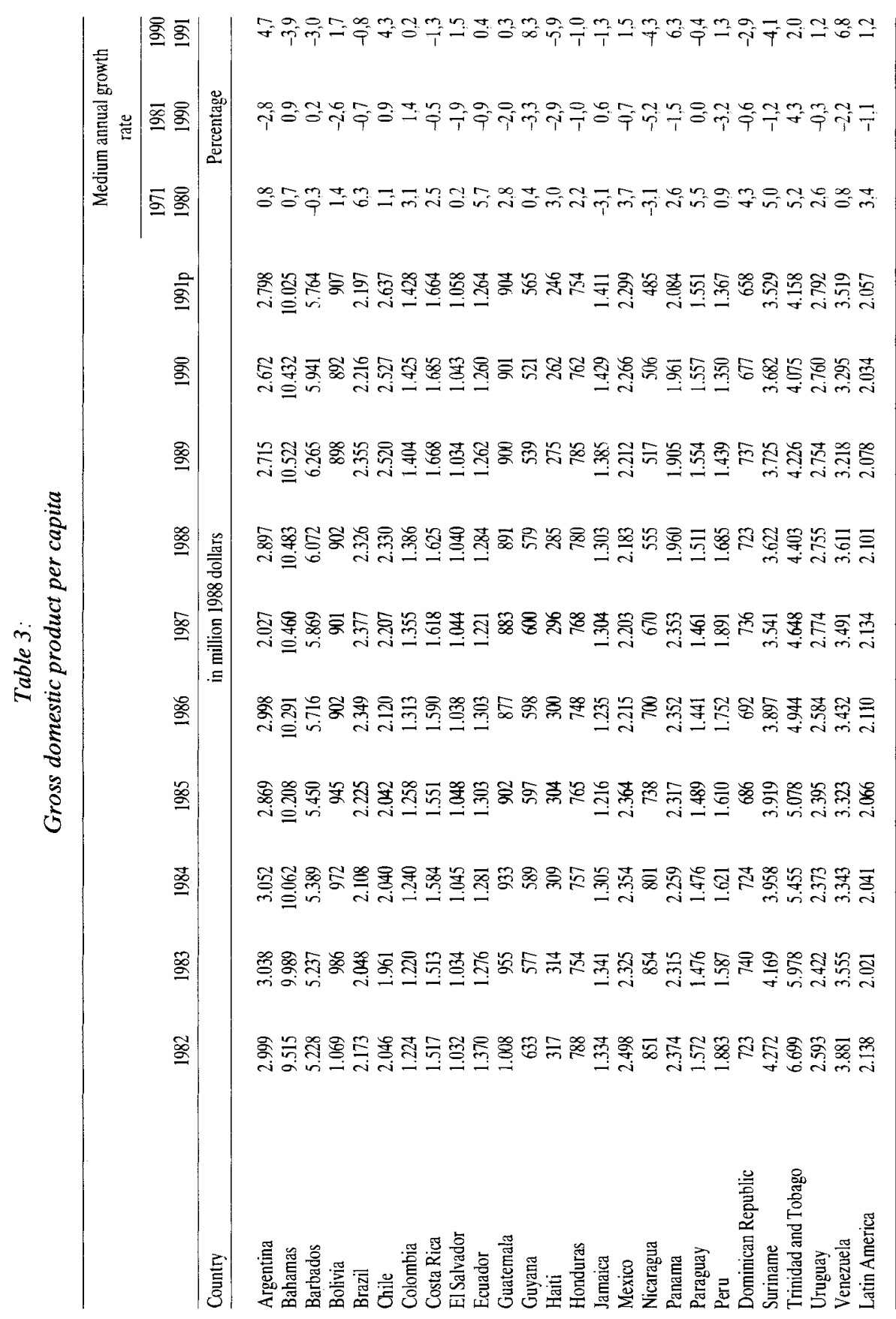

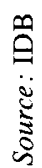


where the general impoverishment is highlighting in the 1980s, a period in which this per capita indicator decreased at a $1.1 \%$ /year basis, after a positive evolution to $3.4 \%$ year from 1971 to 1980 .

In the last years of the series (1990 and 1991), this indicator began to raise again to a rate of $+1.2 \%$ a year.

\section{Latin America's potential - some indicators}

In 1990, Latin America - considered here in its widest configuration, encompassing Caribbean and Central America countries (according to the regional enclosure adopted by IDB - Inter-American Development Bank) - accounted for about $8.5 \%$ of world population and $4.6 \%$ of world GDP.

These values, positively modest as compared to the world scenery, modify in the light of some indicators pertinent to the Potentialities of the focused region. Permanent crops (in 1987) : $30.2 \%$ of world; Potentially cultivatable land: $23.1 \%$ of world; Permanent grazing lands (1987) : $17.7 \%$ of world; Woods and savannahs (1987) : $23.7 \%$ of world and Livestock (1987): $16.3 \%$ of world.

Latin America is certainly a Continent with non-underestimable but extremely important sectorial potentialities that create undoubtedly "maneuver spaces" of great importance and strong significance for the Continent's planning and geo-strategical management.

This assertion can be realized and confirmed by recent studies. The appropriate use of these key features, followed by a competent definition of the economic, social, political, and institutional aspects, will be a crucial means of levering the region's savings, separately or in partnership with foreign countries, by generating projects of utmost importance for the entire Continent.

Latin America's potentialities, together with the non-occurring of racial, religious and ethnical shocks, put the Continent in a priviledged position, so as to attract (and conquest) strategical investments for the region, giving rise to an expressive development of primary, secondary and tertiary sectors of the global economy.

It is in this comprehensive context that the Continent's private insurance sector is inserted and is likely to experience, as we see it, an extraordinary expansion in the years to come, by uniting both the traditional market development and the new responsibilities and/or products - such as the selective interaction procedures with social security, for instance.

The topics below present - in their numerical magnitudes - some relevant aspects of Private Insurance and Social Insurance in Latin America. Finally, there is a description of a few strategical sceneries for the development of private insurance in the Continent.

\section{Private insurance in Latin America}

The private insurance activities in Latin America in 1990 represented only $0.7 \%$ of the total world insurance.

Ten and 30 years ago its share were relatively more expressive, with rates going to $1.0 \%$ and $1.7 \%$, respectively (Table 4 ). 
Table 4:

Share of insurance premiums per country blocks

(in \%)

\begin{tabular}{|l|c|c|c|}
\hline Blocks & 1960 & 1980 & 1990 \\
\hline Africa & 0.9 & 1.3 & 1.1 \\
\hline Latin America & 1.0 & 1.7 & 0.7 \\
\hline Oceania & 1.4 & 2.0 & 1.8 \\
\hline Asia & 3.0 & 15.3 & 24.6 \\
\hline West Europe & 22.7 & 33.0 & 33.9 \\
\hline North America & 71.0 & 46.7 & 37.9 \\
\hline World Total & 100 & 100 & 100 \\
\hline
\end{tabular}

Basic Source: SIGMA / SWISS-RE.

If on the one hand Latin American private insurance market has a share lower than 1 percent of world insurance activities, the Latin American economies, on the other hand, account for approximately $4.6 \%$ of the World GDP, which demonstrates an enormous gap that by itself indicates a restrained potential insurance market.

Tables 5 and 6 present recent detailed data on the private insurance market in Latin America, confronted with data from other countries and regions throughout the world.

Table 5 introduces basic parameters related to private insurance market in Latin America (1990) for six selected countries: Argentina, Brazil, Chile, Colombia, Mexico, and Venezuela.

These countries - with US $\$ 14.9$ billion premiums - represent $90 \%$ of the regional market (see Table 8). In that conditions, the total private insurance market in Latin America - for 1990 , can be estimated in US $\$ 16.6$ billion.

Table 5:

Private insurance in Latin America

Basic parameters / six selected countries

\begin{tabular}{|c|c|c|c|c|c|c|c|}
\hline \multirow{2}{*}{ COUNTRY } & \multirow{2}{*}{$\begin{array}{c}\text { Premiums in } 1990 \\
\text { in Millions of } \\
\text { US-\$ }\end{array}$} & \multicolumn{2}{|c|}{$\begin{array}{l}\text { Breakdown of } \\
\text { overall business }\end{array}$} & \multicolumn{4}{|c|}{$\begin{array}{c}\text { Breakdown of non-life } \\
\text { business }\end{array}$} \\
\hline & & life & non-life & fire & marine & motor & rest \\
\hline Argentina & 3,174 & 8,4 & 91,6 & 10,6 & 6,2 & 57,2 & 26,0 \\
\hline Brazil & 6,537 & 12,7 & 87,3 & 26,5 & 3,7 & 42,6 & 27,2 \\
\hline Chile & 826 & 59,5 & 40,5 & 20,0 & 8,6 & 34,9 & 36,5 \\
\hline Colombia & 724 & 17,8 & 82,2 & 22.4 & 8,8 & 36.5 & 32,3 \\
\hline Mexico & 2,740 & 36,4 & 63,6 & 17,6 & 11.4 & 45,1 & 25,9 \\
\hline Venezuelà & 922 & 5,6 & 94,4 & 14,9 & 6,7 & 30,3 & 48,1 \\
\hline TOTAL & 14,923 & 18,5 & 81,5 & 20,2 & 6,0 & 45,1 & 28,7 \\
\hline
\end{tabular}

Source: SIGMA / SWISS-RE. 
Some facts deserve a special attention:

a) The "non-life" branch is clearly prominent in Latin America (18\% life and $82 \%$ nonlife), contrasting with the world panorama (47\% life versus $53 \%$ non-life) and especially with the Asian region ( $75 \%$ life versus $25 \%$ non-life, in Japanese experience) - (data from 1988).

Table 6:

Premium per capita

(in \$)

\begin{tabular}{|l|r|r|r|}
\hline \multirow{2}{*}{ COUNTRIES } & TOTAL & NON-LIFE & \multicolumn{1}{|c|}{ LIFE } \\
\cline { 2 - 4 } & 1988 & 1988 & 1988 \\
\hline United States & 1.751 .30 & 1.031 .50 & 717.80 \\
Switzerland & 2.323 .50 & 992.60 & 1.330 .90 \\
Spain & 376.49 & 193.20 & 183.20 \\
Greece & 67.30 & 43.70 & 23.60 \\
Turkey & 6.00 & 5.50 & 0.50 \\
Japan & 2.320 .90 & 574.70 & 1.746 .20 \\
South Africa & 251.40 & 54.80 & 196.60 \\
Venezuela & 39.87 & 36.98 & 2.89 \\
Panama & 75.45 & 36.65 & 38.80 \\
Argentina & 65.02 & 59.88 & 5.14 \\
Chile & 37.57 & 18.54 & 19.03 \\
Mexico & 23.26 & 14.83 & 8.43 \\
Colombia & 17.67 & 14.92 & 2.75 \\
Brazil & 21.20 & 18.55 & 2.65 \\
\hline
\end{tabular}

Source: Lecture by José Manuel Mallén, Associaçăo de Resseguradores Latino-Americanos, XVI Assembléia - Revista de Seguros/World Bank.

b) Private insurance premiums per capita in Latin America do not reach $\$ 100$ year, thus remaining at levels extremely distant from those of per capita premiums from the industrialized countries, where the high income levels are translated into high insurance consumption levels. Of course, the concentration of private insurance activities in these more advanced countries is well-known. The 12 major countries in the world, in terms of development and per capita income, account for 66 percent of the World GDP. In fact, $86 \%$ of the world private insurance activity are focused in these countries (data from 1990).

Table 7 provides information on reinsurance achieved abroad related to direct premiums in Latin American countries (1988 and 1989).

It is interesting that the market of direct premiums totalizes about 16,1 (1990) billion/ year, and this total reinsurers abroad approximately $15-16 \%$ of these mobilized volumes (1988 and 1989), within this framework, Brazil reinsured abroad an amount less than $4 \%$ of the total direct premiums in $1988 / 89$, and some $2 \%$ in $1990 / 91$.

Table 8 shows the structural composition of private insurance in Latin America. 
Table 7:

Reinsurance achieved abroad / direct premium, by country

\begin{tabular}{|l|c|c|}
\hline COUNTRIES & $\begin{array}{c}1989 \\
(\%)\end{array}$ & $\begin{array}{c}1988 \\
(\%)\end{array}$ \\
\hline Argentina & 6.39 & 3.78 \\
Brazil & 3.59 & 3.94 \\
Sub-Total & 4.12 & 3.88 \\
Bolivia & 51.03 & 56.06 \\
Colombia & 23.77 & 27.71 \\
Costa Rica & 15.74 & 16.93 \\
Chile & 25.39 & 26.29 \\
Ecuador & 66.08 & 69.48 \\
El Salvador & 53.76 & 58.49 \\
Guatemala & 39.76 & 40.67 \\
Haiti & 98.13 & 43.97 \\
Honduras & 45.87 & 90.00 \\
Jamaica & 45.48 & 45.00 \\
Mexico & 16.49 & 18.59 \\
Nicaragua & 27.14 & 13.64 \\
Panama & 38.98 & 25.35 \\
Paraguay & 52.85 & 54.69 \\
Peru & 45.99 & 40.22 \\
Dominican Rep. & 33.48 & 34.10 \\
Trinidad & 53.00 & 53.00 \\
Uruguay & 10.00 & 15.22 \\
Venezuela & 24.00 & 24.00 \\
Sub-Total & 23.77 & 26.30 \\
Total & 15.83 & 14.97 \\
\hline
\end{tabular}

Source: Lecture by José Manuel Mallén, Associação de Resseguradores Latino-Americanos, XVI Assembléia - Revista de Seguros.

Brazil plays here a major role, for its participation ranges between $30 \%$ and $40 \%$ of Latin American direct insurance premiums, followed by Mexico, which has remarkably developed this market (the $11 \%$ rate in 1986 went up to $23 \%$ in 1989). Two other countries are worth mentioning in this context: Venezuela and Chile. The former raised its participation from $6.5 \%$ in 1986 to $8.3 \%$ in 1989 and the latter has also been augmenting its market share, namely from $4.1 \%$ in 1986 to $5.5 \%$ in 1989 .

As to the insurance premium's share of GDP, by considering as a whole the six major Latin American countries in the field of private insurance ( $86 \%$ of the total market), we verify that in 1960-1990 (see Table 9) none of these countries exceeded the rate of 3 percent. Brazil's share, for instance, remained around $1 \%$ in these 30 years. 
Table 8:

Insurance premiun ranking - by countries

\begin{tabular}{|c|c|c|c|c|c|c|c|c|}
\hline \multirow[b]{2}{*}{ Country } & \multicolumn{2}{|c|}{1989} & \multicolumn{2}{|c|}{1988} & \multicolumn{2}{|c|}{1987} & \multicolumn{2}{|c|}{1986} \\
\hline & \multicolumn{2}{|c|}{ Position $\%$} & \multicolumn{2}{|c|}{ Position $\%$} & \multicolumn{2}{|c|}{ Position $\%$} & \multicolumn{2}{|c|}{ Position } \\
\hline Brazil & 1 & 35.11 & 1 & 33.16 & 1 & 38.08 & 1 & 31.30 \\
\hline Mexico & 2 & 23.32 & 2 & 21.08 & 3 & 12.07 & 3 & 11.24 \\
\hline Venezuela & 3 & 8.27 & 4 & 6.98 & 4 & 7.15 & 4 & 6.53 \\
\hline Argentina & 4 & 8.16 & 3 & 13.68 & 2 & 12.76 & 2 & 25.04 \\
\hline Colombia & 5 & 6.86 & 5 & 6.06 & 5 & 6.98 & 5 & 5.58 \\
\hline Chile & 6 & 5.47 & 6 & 5.21 & 6 & 5.25 & 6 & 4.05 \\
\hline Peru & 7 & 2.17 & 7 & 2.63 & 7 & 3.44 & 7 & 3.40 \\
\hline Jamaica & 8 & 1.37 & 10 & 1.35 & 10 & 1.62 & 17 & 0.70 \\
\hline Uruguay & 9 & 1.34 & 11 & 1.27 & 14 & 1.11 & 14 & 0.97 \\
\hline Trinidad & 10 & 1.33 & 9 & 1.40 & 9 & 1.90 & 9 & 1.74 \\
\hline Panama & 11 & 1.27 & 8 & 1.88 & 8 & 2.73 & 8 & 2.54 \\
\hline Costa Rica & 12 & 1.05 & 12 & 1.00 & 13 & 1.15 & 12 & 1.02 \\
\hline Dominican Rep. & 13 & 1.01 & 13 & 0.95 & 11 & 1.29 & 11 & 1.12 \\
\hline Ecuador & 14 & 0.83 & 14 & 0.72 & 15 & 1.02 & 10 & 1.13 \\
\hline Guatemala & 15 & 0.64 & 16 & 0.67 & 12 & 1.24 & 15 & 0.82 \\
\hline El Salvador & 16 & 0.55 & 15 & 0.70 & 16 & 0.79 & 18 & 0.54 \\
\hline Honduras & 17 & 0.37 & 17 & 0.62 & 17 & 0.78 & 16 & 0.70 \\
\hline Bolivia & 18 & 0.26 & 18 & 0.28 & 18 & 0.30 & 19 & 0.24 \\
\hline Haiti & 19 & 0.23 & 20 & 0.11 & 20 & 0.11 & 21 & 0.13 \\
\hline Paraguay & 20 & 0.20 & 19 & 0.18 & 19 & 0.20 & 20 & 0.21 \\
\hline \multirow[t]{2}{*}{ Nicaragua } & 21 & 0,17 & 21 & 0.07 & 21 & 0.03 & 13 & 1.00 \\
\hline & & 100.00 & & 100.0 & & 100.0 & & 100.0 \\
\hline
\end{tabular}

Source: Lecture by José Manuel Mallén, Associação de Resseguradores Latino-Americanos, XVI Assembléia - Revista de Seguros.

Table 9:

Ratios of insurance premiums to GDP in Latin America (\%)

\begin{tabular}{l|c|c|c|c|c}
\hline Country & 1960 & 1970 & 1980 & 1985 & 1990 \\
\hline Argentina & 1.13 & 1.71 & 1.22 & 2.37 & - \\
Brazil & 0.78 & 0.86 & 0.93 & 0.89 & 1.30 \\
Chile & - & - & 0.91 & 1.98 & 2.97 \\
Colombia & - & - & 1.19 & 1.40 & 1.80 \\
Mexico & 0.78 & 0.88 & 0.82 & 1.12 & - \\
Venezuela & 0.96 & 1.35 & 1.86 & 2.68 & 1.91 \\
\hline
\end{tabular}


Table 10 shows the figures for the ratio of insurance premiums elasticity ${ }^{2}$ to GDP for the six major Latin American countries. This table portrays the relationships between premiums growth rates and the related GDP growth rates for different periods from 1960 to 1990. In most cases these ratios remained between 1 and 1.20 , except in one occasion, where the ratio was above 1.50 .

Table 10:

Ratio of insurance premium elasticity to $G D P$ in Latin American countries

\begin{tabular}{l|c|c|c|c}
\hline Countries & $60-90$ & $70-90$ & $80-90$ & $85-90$ \\
\hline & $(60-80)$ & $(70-88)$ & $(80-88)$ & $(85-88)$ \\
Argentina & 1.06 & 1.04 & 1.15 & 1.07 \\
Brazil & 1.04 & 1.04 & 1.05 & 1.10 \\
Chile & - & - & 1.67 & 1.40 \\
Colombia & - & - & 1.19 & 1.21 \\
Mexico & - & - & 0.91 & 0.82 \\
Venezuela & 1.17 & 1.10 & 1.01 & 0.79 \\
\hline
\end{tabular}

Source: Insurance Data Bank / CONSULTEC

Table 11:

Number of insurance and reinsurance companies in selected Latin American countries $1990-91$

\begin{tabular}{|c|c|c|}
\hline Countries & No. of ins. comp. & No. of reins. comp. \\
\hline Argentina & 220 & 1 \\
\hline Brazil & 127 & 1 \\
\hline Chile & 45 & 3 \\
\hline Colombia & 55 & 3 \\
\hline Mexico & 42 & 2 \\
\hline Peru & 18 & 1 \\
\hline Bolivia & 18 & NA \\
\hline Costa Rica & 1 & 1 \\
\hline Ecuador & 32 & 2 \\
\hline Panama & 22 & \\
\hline Paraguay & 42 & 1 \\
\hline Uruguay & 12 & - \\
\hline Total & 634 & 15 \\
\hline
\end{tabular}

2 The elasticity ratio can be defined by:

$\mathrm{e}=\frac{\text { Premium Relative Increase in the Period }}{\text { GDP Relative Increase in the Period. }}$ 
There are more than 650 insurance and reinsurance companies in Latin America, according to the estimated basis displayed in Table 11, by adding some countries not presented before because there were no available updated data.

Considering the Chile-Colombia-Mexico-Ecuador-segment, the ratio of number of insurance companies to number of reinsurance companies is equal 17.

\section{Security and social insurance in Latin America: \\ Evolution and present situation/major aspects}

In the scope of the social programs designed by organized governments, the social security activities play an important part. Social Security may be understood as a set of programs ruled by the public sector, including the following segments, among others: General social benefits, family allowance, social assistance, health assistance public programs, national health schemes, and special programs, such as the aid for war victims, for instance.

Social security includes social insurance, which is responsible for programs concerning the benefit area: retirement benefit, pensions, industrial accident compensation, medical and hospital care, unemployment insurance, and other selected attendance goods that can also be translated into monetary benefits.

The actual concerns for population's social welfare are some of the main features of social security.

Social insurance, in turn, is characterized by a much higher degree of sophistication, for it operates in the field of well-defined compulsory payments and financial allocations under a series of pre-established rules. This kind of insurance is intended to operate as much as possible like a self-sustained and really productive (effective) one, in the accomplishment of its programs. Since the 1920s Latin America has been implanting and amplifying its Welfare Assistance System (or social insurance).

The ILO (International Labor Organization) data currently available - the most comprehensive information on the question of World Security - are presented in historical series (not necessarily continual) till the year of 1986 . This survey is by far more reliable than any other, even the most recent ones.

It is important to point out that social security contains the social insurance - see ILO's XIII INTERNATIONAL INQUIRY (Comparative Tables).

It must be noted that ILO Tables provide information on each selected country - from a much wider block of countries in the international scenery.

Among these, two sets of information have been selected:

a) Social Security Revenues - as a percent of GDP, 1965-1980.

b) Social Insurance in the Social Security.

One can observe that, by combining the information in the first two groups, the resulting data refer to the social insurance shares of the corresponding GDPs, by inference. It is clear that the estimates obtained may not correspond exactly to the effective values (either for methodological, exchange or conceptual reasons), but they certainly allow a macrovisualization of the global scenery of social insurance in Latin America and in selected countries throughout the world (see Table 12). 
Table 12:

Social insurance in Latin America - estimates for 1990

\begin{tabular}{|c|c|c|c|c|c|}
\hline \multirow[t]{2}{*}{ Countries } & \multicolumn{2}{|c|}{$\begin{array}{c}\text { Social insurance GDP } 1990 \\
\text { (\$ Million) }\end{array}$} & \multirow[t]{2}{*}{$\begin{array}{l}\text { Estimated social } \\
\text { insur. }(\$ \mathrm{Mio})\end{array}$} & \multirow[t]{2}{*}{$\begin{array}{l}\text { Popul. } 1990 \\
\text { (in } 1,000 \text { ) }\end{array}$} & \multirow[t]{2}{*}{$\begin{array}{l}\text { Estim. per capita } \\
\text { social insur. }(\$)\end{array}$} \\
\hline & in GDP $(\%)^{1}$ & (World Bank) & & & \\
\hline Argentina & 5.2 & 93,260 & $4,849.5$ & 32,322 & 150.04 \\
\hline Bahamas & 3.3 & ${ }^{2}$ N.A. & N.A. & 255 & ${ }^{3} \mathrm{NE}$ \\
\hline Barbados & 5.3 & N.A. & N.A. & 255 & $\mathrm{NE}$ \\
\hline Bolivia & 2.5 & 4,480 & 112.0 & 7,314 & 15.31 \\
\hline Brazil & 5.3 & 414,060 & $21,945.2$ & 150,368 & 145.94 \\
\hline Chile & 16.9 & 27,790 & $4,696.5$ & 13,173 & 356.53 \\
\hline Colombia & 1.5 & 41,120 & 616.8 & 32,978 & 18.70 \\
\hline Costa Rica & 9.4 & 5,700 & 535.8 & 3,015 & 177.71 \\
\hline El Salvador & 1.4 & 5,400 & 75.6 & 5,252 & 14.39 \\
\hline Ecuador & 5.8 & 10,880 & 631.0 & 10,587 & 59.61 \\
\hline Guatemala & 1.3 & 7,630 & 99.2 & 9,197 & 10.79 \\
\hline Guyana & 8.4 & N. A. & N. A. & 755 & $\mathrm{NE}$ \\
\hline Haiti & N. A. & 2,760 & N. A. & 6,513 & $\mathrm{NE}$ \\
\hline Honduras & 2.0 & 2,360 & 47.2 & 5,138 & 9.19 \\
\hline Jamaica & 0.8 & 3,970 & 31.8 & 2,521 & 12.60 \\
\hline Mexico & 2.0 & 237,750 & $4,755.0$ & 81,250 & 58.52 \\
\hline Nicaragua & 1.8 & N.A. & N.A. & 3,871 & $\mathrm{NE}$ \\
\hline Panama & 9.2 & 4,750 & 437.0 & 2,418 & 180.73 \\
\hline Paraguay & N.A. & 5,260 & N.A. & 4,277 & $\mathrm{NE}$ \\
\hline Peru & 1.8 & 36,550 & 657.9 & 21,550 & 30.53 \\
\hline Dominican Rep. & 0.5 & 7,310 & 36.6 & 7,170 & 5.10 \\
\hline Suriname & 1.2 & N. A. & N.A. & 364 & $\mathrm{NE}$ \\
\hline Trinidad \& Tobago & 2.5 & 4,750 & 118.8 & 1,215 & 97.74 \\
\hline Uruguay & 9.0 & 8,220 & 739.8 & 3,094 & 239.11 \\
\hline Venezuela & 1.5 & 48,270 & 724.1 & 19,735 & 36.69 \\
\hline TOTAL & 4,2 & 972,270 & $41,109.7$ & 424,587 & 96.82 \\
\hline
\end{tabular}

1 Values referring to 1986. At an estimate basis only, these coefficients have been transposed to the year 1990 , so as to obtain hypothetical indicators, in a first approach.

2 Data not available.

${ }^{3} \mathrm{NE}=$ data not estimated.

Main source: ILO/Derived Estimates.

Because financial bulk of social security and social insurance is too voluminous within each country's economy, in a first approach the premise to be adopted is based on the possible transposition of the social security and insurance shares of 1986 GDPs to the year 1990. Thus, Table 12 has been structured so as to find out the estimated incidence of social insurance in Latin American countries in 1990. As mentioned before, the estimates are drawn from ILO's survey. 
These are the main points standing out from the values concerning Latin America's positioning:

a) The shares of social insurance in social security are as a rule superior to 75 percent, with few exceptions.

b) The shares of social insurance in the GDPs of selected countries vary considerably, from about $0.5 \%$ (Dominican Rep.) to $17 \%$ (Chile).

c) In a decreasing scale, the major social insurance contributions were as follows:
1) Brazil:
$\$ 22$ billion $(5.3 \%$ from GDP)
2) Argentina:
$\$ 4.9$ billion $(5.2 \%$ from GDP)
3) Mexico:
$\$ 4.8$ billion ( $2.0 \%$ from GDP)
4) Chile :
$\$ 4.7$ billion ( $16.9 \%$ from GDP)
5) Uruguay:
$\$ 0.74$ billion ( $9.0 \%$ from GDP)
6) Venezuela:
$\$ 0.72$ billion (1.5\% from GDP)
7) Peru:
$\$ 0.66$ billion (1.8\% from GDP)
8) Ecuador:
$\$ 0.63$ billion (5.8\% from GDP)
9) Colombia:
$\$ 0.62$ billion ( $1.5 \%$ from GDP)

d) The figures for the estimated revenues from per capita social insurance varied in 1990 , from $\$ 5$ to $\$ 357$, in the following order:

$\begin{array}{ll}\text { Chile: } & \$ 357 / \text { year } \\ \text { Uruguay: } & \$ 239 / \text { year } \\ \text { Costa Rica: } & \$ 178 / \text { year } \\ \text { Argentina: } & \$ 150 / \text { year } \\ \text { Brazil: } & \$ 146 / \text { year } \\ \text { Trinidad and Tobago: } & \$ 98 / \text { year } \\ \text { Ecuador: } & \$ 60 / \text { year } \\ \text { Mexico: } & \$ 59 / \text { year } \\ \text { Venezuela: } & \$ 37 / \text { year } \\ \text { Peru: } & \$ 31 / \text { year } \\ \text { Colombia: } & \$ 19 / \text { year } \\ \text { Bolivia: } & \$ 15 / \text { year } \\ \text { El Salvador: } & \$ 14 / \text { year } \\ \text { Jamaica: } & \$ 13 / \text { year } \\ \text { Guatemala: } & \$ 11 / \text { year } \\ \text { Honduras: } & \$ 99 / \text { year } \\ \text { Dominican Rep.: } & \$ 5 / \text { year }\end{array}$

e) It is important to remark that the average level of social insurance for all Latin American countries is $4 \%$ of the total GDP; the countries above this average are Chile $(16.9 \%)$, Uruguay $(9 \%)$, Jamaica $(8.4 \%)$, Ecuador (5.8\%), Brazil $(5.3 \%)$, Argentina $(5.2 \%)$, Costa Rica $(9.4 \%)$, Guyana $(8.4 \%)$, and Barbados $(5.3 \%)$

f) These values of social insurance shares of GDP may be found in quite diversified ranges of each country's economic positioning, in terms of per capita GNP, thereby reflecting concerns and actions at distinct intensities, according to the economic position level of Latin American countries (Table 13). 
Table 13:

Per capita GNP and social insurance levels in GDP in Latin America

\begin{tabular}{|l|c|c|}
\hline COUNTRIES & $\begin{array}{c}\text { Per capita GNP } \\
1990(\$)\end{array}$ & $\begin{array}{c}\text { Social insurance } \\
\text { in GNP }(\%)\end{array}$ \\
\hline Bolivia & 630 & 2.5 \\
Ecuador & 980 & 1.4 \\
Peru & 1.160 & 1.8 \\
Colombia & 1.260 & 1.5 \\
Costa Rica & 1.900 & 9.4 \\
Chile & 1.940 & 16.9 \\
Argentina & 2.370 & 5.2 \\
Mexico & 2.490 & 2.0 \\
Venezuela & 2.560 & 1.5 \\
Uruguay & 2.560 & 9.0 \\
Brazil & 2.680 & 5.3 \\
\hline
\end{tabular}

Source: World Bank and Table 12.

Costa Rica and Chile, with per capita GNPs close to $\$ 2,000$, have the highest social insurance shares of GDP. Ecuador, Peru and Colombia, with per capita GNPs around $\$ 1,000$, show modest percentages, ranging from $1.4 \%$ to $1.8 \%$ of social insurance/GDP, and these levels are lower than those of Bolivia with a figure of $\$ 630$ per capita GNP, and equal to those of Venezuela with a figure of $\$ 2,560$ per capita GNP. Brazil and Argentina present virtually the same percentages for slightly different per capita product figures $(\$ 2,680$ and $\$ 2,370$, respectively).

\section{Social insurance in the $\mathbf{1 2}$ most developed economies: Latin America's relative position}

In order to obtain a comparative overview of Latin America's position in global economy and in the industrialized countries' social insurance, a sample with the 12 major world economies which account for $66 \%$ of World GDP has been selected. This group is composed of the United States, Japan, Germany, France, Italy, Great-Britain, Canada, Spain, Australia, Netherlands, Sweden and Switzerland.

Table 14 summarizes the main variables relative to social security, in absolute figures and relative figures, and per capita values, ${ }^{3}$ concerning the GDPs of these countries.

The high per capita GDP rates of these countries, at an average of $\$ 20,575$ per capita (1990), reflect the high share levels of social security and social insurance in the 12 economies' respective products.

${ }^{3}$ Social Insurance per capita - Estimate (1990): Australia (US $\$ 1268$ ); Great Britain (US $\$ 1796$ ); Italy (US \$1827); Spain (US \$1958); USA (US \$ 2079); Japan (US \$2658); Canada (US \$2894); Germany (US $\$ 3480$ ); France (US $\$ 3946$ ); Netherlands (US $\$ 4705$ ); Switzerland (US $\$ 4531$ ) and Sweden (US \$ 6558). 
Table 14:

Social security and social insurance ranks in the 12 major world economies

\begin{tabular}{|l|c|c|c|}
\hline & Social security & \multicolumn{2}{|c|}{ Social insurance } \\
\hline & GDP (\%) & per capita (\$) & GDP (\%) \\
\hline Minimal & $9.3^{1}$ & $1,268^{1}$ & $7.3^{1}$ \\
\hline Mean & 19.8 & 2,560 & 12.4 \\
\hline Maximal & $32.7^{2}$ & $6,558^{3}$ & $25.1^{2}$ \\
\hline
\end{tabular}

1 Australia

2 Netherlands

${ }^{3}$ Sweden

In this panorama, the position of Latin America's Social Insurance is quite modest. First of all, since its income levels are small, only $4 \%$ of the GDP are designed to Latin American social insurance; in this region, the per capita GDP average level $(\$ 2,290)$ corresponds to a per capita social insurance revenue of $\$ 96$ (see Table 12). At the other extreme, the 12 world most advanced economies have about $12.4 \%$ of GDP, on the average, associated to the resources from social insurance; besides, an average per capita GDP of $\$ 20,575$ in these countries correspond to an average per capita social insurance of $\$ 2,560$.

Such figures for developed countries show a potential positioning for Latin America of utmost importance. In other words, the international experience deals with extremely significant expenditure levels, which indicate that social insurance is likely to expand considerably in the future, in this Continent - to the extent that the CONTINENT AREA accelerates its economic development process. In this context, the social insurance may be included as an Effective Activator, as long as expressive budget portions be eventually allocated in it from social security.

To have an idea of the extent of this question, let us point out that the estimated movement of social insurance in Latin America amounts to about $\$ 40$ billion/year, which represents four times the region's private insurance direct premiums as a whole (approximately $\$ 10,4$ billion).

A simple juxtaposition of these figures shows that any institutional shifting of social insurance towards private insurance will expand significantly the operational levels of the private segment.

\section{Predictable sceneries for the private insurance market in Latin America}

The expansion of Latin America's private insurance market in the 1990s will rely mainly on the following factors, based upon the aspects previously described:

i) Economic growth and monetary stability in the Region;

ii) Selective levels of interaction between private insurance and the Latin-American process of economic growth;

iii) Specific transfers of certain social security segments to the scope of private insurance. 
In the 1980s, Latin America - as a whole - grew modestly, at a rate of $1.1 \%$ annually, a level quite lower than the $5.9 \%$ a year achieved in the 1970 s. On the other hand, the Region is recovering economic drive, for in 1991 it attained a growth of $3.2 \%$ relative to the preceding year.

The modernizing attitudes that have been translated into practical policies in a number of countries, particularly Mexico, Chile and Argentina, in conjunction with the immense regional potentialities, allow us to determine, as a projections basis for the $1990 \mathrm{~s}$, the eventual occurrence of a superior hypothesis of economic growth around 6 percent a year.

It is possible to establish a rate of $2 \%$ a year as an inferior hypothesis of economic growth, and an intermediate rate of $4 \%$ a year and a superior rate of $6 \%$ a year (see tables 15,16 and 17).

Concomitantly to these economic growth hypotheses, some operational premises may be adopted for the prospects of Latin America's behavior in terms of private insurance market in the year 2000 . Such premises would be as follows:

i) traditional market, which is now around $\$ 16,6$ billion is supposed to grow at exactly the same rate as that of the region's economy (elasticity 1 );

ii) social insurance, amounting to some $\$ 41$ billion in today figures, will also develop according to the region's GDP growth rate (elasticity 1 );

iii) at the end of the decade a proportion of social insurance is to be transferred to the sphere of private insurance; so, by 2000 it is possible that $10 \%-20 \%$ of social insurance will be under the private sector.

The tables below particularize calculations for the projections of private and social insurance markets around the year 2000 , taking into account growth rates as well as transfers of $10 \%, 15 \%$ and $20 \%$ from social insurance to private insurance.

Stress must be laid on the fact that, in the presumption of a transfer from social to private insurance under the conditions here considered, there would be a growth of $25 \%$ to $37 \%$ and $50 \%$ in the (presently traditional) private insurance market, by its incorporation of $10 \%$, then $15 \%$ and $20 \%$ from social insurance, respectively, till the end of the decade.

Moreover, it is worthy of notice that such hypotheses are consistent with the expressive reconfiguration of private insurance structure in life and non-life branches. In the early 1990s, they were so distributed: $18 \%$ for the life branch and $82 \%$ for the non-life one. Under the hypothesis of $20 \%$ from social insurance being transferred to private insurance, this distribution is likely to change: the life branch (which will incorporate the portion moved from social insurance) is expected to raise up to $45 \%$ - a rate much nearer the average world one, which is now $52 \%$.

It is instigating to find out that the recovering of development and the new culturalbusiness behaviors may practically triplicate the Latin American market by the year 2000 . Some behaviors already indicate that it is not impossible to cope with such a challenge. To achieve its full potential, our private insurance sector must be well prepared, and strongly engaged, reckoning upon the support of the developed world, for us to reach - or even exceed - the highest limit of the identified sceneries.

By hitting this target, we shall be - more and more - capable of collaborating for Latin American global process of social and economic development in this end of century and dawn of the Third Millenium. 
Table 15:

Expansion of Latin American private insurance market Basic sceneries - (1990-2000)

Hypothesis: $10 \%$ (in \$ billion)

\begin{tabular}{|c|c|c|c|c|c|c|}
\hline \multirow{2}{*}{ ITEMS } & \multicolumn{6}{|c|}{ ECONOMY GROWTH RATE } \\
\hline & \multicolumn{2}{|c|}{$2 \%$ a year } & \multicolumn{2}{|c|}{$4 \%$ a year } & \multicolumn{2}{|c|}{$6 \%$ a year } \\
\hline \multicolumn{7}{|l|}{$\begin{array}{l}\text { 1) TRADITIONAL PRIVATE INSURANCE } \\
(1990)\end{array}$} \\
\hline 1.1 - NON LIFE & \multicolumn{2}{|c|}{13,6} & \multicolumn{2}{|c|}{13,6} & \multicolumn{2}{|c|}{13,6} \\
\hline 1.2 - LIFE & \multicolumn{2}{|c|}{3,0} & \multicolumn{2}{|c|}{3,0} & \multicolumn{2}{|c|}{3,0} \\
\hline 1.3 - TOTAL & \multicolumn{2}{|c|}{16,6} & \multicolumn{2}{|c|}{16,6} & \multicolumn{2}{|c|}{16,6} \\
\hline \multicolumn{7}{|l|}{$\begin{array}{l}\text { 2) TRADITIONAL PRIVATE INSURANCE } \\
\text { PROJECTION - } 2000\end{array}$} \\
\hline 2.1 - NON-LIFE & \multicolumn{2}{|c|}{16,6} & \multicolumn{2}{|c|}{20,1} & \multicolumn{2}{|c|}{24,4} \\
\hline $2.2-$ LIFE & \multicolumn{2}{|c|}{3,6} & \multicolumn{2}{|c|}{4,4} & \multicolumn{2}{|c|}{5,4} \\
\hline 2.3 - TOTAL & \multicolumn{2}{|c|}{20,2} & \multicolumn{2}{|c|}{24,5} & \multicolumn{2}{|c|}{29,8} \\
\hline $\begin{array}{l}\text { 3) SOCIAL INSURANCE - } 1 \\
(1989 / 1990)\end{array}$ & \multicolumn{2}{|c|}{41,1} & \multicolumn{2}{|c|}{41,1} & \multicolumn{2}{|c|}{41,1} \\
\hline $\begin{array}{l}\text { 4) SOCIAL INSURANCE } \\
\text { PROJECTION - } 2000\end{array}$ & \multicolumn{2}{|c|}{50,1} & \multicolumn{2}{|c|}{60,8} & \multicolumn{2}{|c|}{73,6} \\
\hline $\begin{array}{l}\text { 5) SOCIAL INSURANCE SHARE TO BE } \\
(10 \%) \text { TRANSFERRED TO PRIVATE } \\
\text { INSURANCE (2000) }\end{array}$ & \multicolumn{2}{|c|}{5,0} & \multicolumn{2}{|c|}{6,1} & \multicolumn{2}{|c|}{7,4} \\
\hline \multicolumn{7}{|l|}{$\begin{array}{l}\text { 6) EXPANDED PRIVATE INSURANCE } \\
(2000)=(2.3)+(5)\end{array}$} \\
\hline $6.1-$ NON LIFE & 16,6 & $66 \%$ & 20,1 & $66 \%$ & 24,4 & $66 \%$ \\
\hline 6.2. - LIFE & 8,6 & $34 \%$ & 10,5 & $34 \%$ & 12,8 & $34 \%$ \\
\hline 6.3 - TOTAL & 25,2 & $100 \%$ & 30,6 & $100 \%$ & 37,8 & $100 \%$ \\
\hline
\end{tabular}


Table 16:

Expansion of Latin American private insurance market Basic sceneries - (1990-2000)

Hypothesis: $15 \%$ (in $\$$ billion)

\begin{tabular}{|c|c|c|c|c|c|c|}
\hline \multirow{2}{*}{ ITEMS } & \multicolumn{6}{|c|}{ ECONOMY GROWTH RATE } \\
\hline & \multicolumn{2}{|c|}{$2 \%$ a year } & \multicolumn{2}{|c|}{$4 \%$ a year } & \multicolumn{2}{|c|}{$6 \%$ a year } \\
\hline \multicolumn{7}{|l|}{$\begin{array}{l}\text { 1) TRADITIONAL PRIVATE INSURANCE } \\
(1990)\end{array}$} \\
\hline $1.1-$ NON LIFE & \multicolumn{2}{|c|}{13,6} & \multicolumn{2}{|c|}{13,6} & \multicolumn{2}{|c|}{13,6} \\
\hline 1.2 - LIFE & \multicolumn{2}{|c|}{3,0} & \multicolumn{2}{|c|}{3,0} & \multicolumn{2}{|c|}{3,0} \\
\hline 1.3 - TOTAL & \multicolumn{2}{|c|}{16,6} & \multicolumn{2}{|c|}{16,6} & \multicolumn{2}{|c|}{16,6} \\
\hline \multicolumn{7}{|l|}{$\begin{array}{l}\text { 2) TRADITIONAL PRIVATE INSURANCE } \\
\text { PROJECTION - } 2000\end{array}$} \\
\hline $2.1-\mathrm{NON}-\mathrm{LIFE}$ & \multicolumn{2}{|c|}{16,6} & \multicolumn{2}{|c|}{20,1} & \multicolumn{2}{|c|}{24,4} \\
\hline $2.2-\mathrm{LIFE}$ & \multicolumn{2}{|c|}{3,6} & \multicolumn{2}{|c|}{4,4} & \multicolumn{2}{|c|}{5,4} \\
\hline $2 . \dot{3}$ - TOTAL & \multicolumn{2}{|c|}{20,2} & \multicolumn{2}{|c|}{24,5} & \multicolumn{2}{|c|}{29,8} \\
\hline $\begin{array}{l}\text { 3) SOCIAL INSURANCE - } 1 \\
(1989 / 1990)\end{array}$ & \multicolumn{2}{|c|}{41,1} & \multicolumn{2}{|c|}{41,1} & \multicolumn{2}{|c|}{41,1} \\
\hline $\begin{array}{l}\text { 4) SOCIAL INSURANCE } \\
\text { PROJECTION - } 2000\end{array}$ & \multicolumn{2}{|c|}{50,1} & \multicolumn{2}{|c|}{60,8} & \multicolumn{2}{|c|}{73,6} \\
\hline $\begin{array}{l}\text { 5) SOCIAL INSURANCE SHARE TO BE } \\
(15 \%) \text { TRANSFERRED TO PRIVATE } \\
\text { INSURANCE }(2000)\end{array}$ & \multicolumn{2}{|c|}{7,5} & \multicolumn{2}{|c|}{9,1} & \multicolumn{2}{|c|}{11,0} \\
\hline \multicolumn{7}{|l|}{$\begin{array}{l}\text { 6) EXPANDED PRIVATE INSURANCE } \\
(2000)=(2.3)+(5)\end{array}$} \\
\hline 6.1 - NON LIFE & 16,6 & $60 \%$ & 20,1 & $60 \%$ & 24,4 & $60 \%$ \\
\hline 6.2. - LIFE & 11,1 & $40 \%$ & 13,5 & $40 \%$ & 16,4 & $40 \%$ \\
\hline 6.3 - TOTAL & 27,7 & $100 \%$ & 33,6 & $100 \%$ & 40,8 & $100 \%$ \\
\hline
\end{tabular}


Table 17:

Expansion of Latin American private insurance market Basic sceneries - (1990-2000)

Hypothesis: $20 \%$ (in $\$$ billion)

\begin{tabular}{|c|c|c|c|c|c|c|}
\hline \multirow{2}{*}{ ITEMS } & \multicolumn{6}{|c|}{ ECONOMY GROWTH RATE } \\
\hline & \multicolumn{2}{|c|}{$2 \%$ a year } & \multicolumn{2}{|c|}{$\overline{4 \%}$ a year } & \multicolumn{2}{|c|}{$6 \%$ a year } \\
\hline \multicolumn{7}{|l|}{$\begin{array}{l}\text { 1) TRADITIONAL PRIVATE INSURANCE } \\
(1990)\end{array}$} \\
\hline $1.1-$ NON LIFE & \multicolumn{2}{|c|}{13,6} & \multicolumn{2}{|c|}{13,6} & \multicolumn{2}{|c|}{13,6} \\
\hline $1.2-\mathrm{LIFE}$ & \multicolumn{2}{|c|}{3,0} & \multicolumn{2}{|c|}{3,0} & \multicolumn{2}{|c|}{3,0} \\
\hline 1.3 - TOTAL & \multicolumn{2}{|c|}{16,6} & \multicolumn{2}{|c|}{16,6} & \multicolumn{2}{|c|}{16,6} \\
\hline \multicolumn{7}{|l|}{$\begin{array}{l}\text { 2) TRADITIONAL PRIVATE INSURANCE } \\
\text { PROJECTION - } 2000\end{array}$} \\
\hline $2.1-$ NON-LIFE & \multicolumn{2}{|c|}{16,6} & \multicolumn{2}{|c|}{20,1} & \multicolumn{2}{|c|}{24,4} \\
\hline $2.2-\mathrm{LIFE}$ & \multicolumn{2}{|c|}{3,6} & \multicolumn{2}{|c|}{4,4} & \multicolumn{2}{|c|}{5,4} \\
\hline 2.3 - TOTAL & \multicolumn{2}{|c|}{20,2} & \multicolumn{2}{|c|}{24,5} & \multicolumn{2}{|c|}{29,8} \\
\hline $\begin{array}{l}\text { 3) SOCIAL INSURANCE - } 1 \\
(1989 / 1990)\end{array}$ & \multicolumn{2}{|c|}{41,1} & \multicolumn{2}{|c|}{41,1} & \multicolumn{2}{|c|}{41,1} \\
\hline $\begin{array}{l}\text { 4) SOCIAL INSURANCE } \\
\text { PROJECTION - } 2000\end{array}$ & \multicolumn{2}{|c|}{50,1} & \multicolumn{2}{|c|}{60,8} & \multicolumn{2}{|c|}{73,6} \\
\hline $\begin{array}{l}\text { 5) SOCIAL INSURANCE SHARE TO BE } \\
(20 \%) \text { TRANSFERRED TO PRIVATE } \\
\text { INSURANCE }(2000)\end{array}$ & \multicolumn{2}{|c|}{10,0} & \multicolumn{2}{|c|}{12,2} & \multicolumn{2}{|c|}{14,7} \\
\hline \multicolumn{7}{|l|}{$\begin{array}{l}\text { 6) EXPANDED PRIVATE INSURANCE } \\
(2000)=(2.3)+(5)\end{array}$} \\
\hline $6.1-$ NON LIFE & 16,6 & $55 \%$ & 20,1 & $55 \%$ & 24,4 & $55 \%$ \\
\hline 6.2. - LIFE & 13,6 & $45 \%$ & 16,6 & $45 \%$ & 20,1 & $45 \%$ \\
\hline 6.3 - TOTAL & 30,2 & $100 \%$ & 36,7 & $100 \%$ & 44,6 & $100 \%$ \\
\hline
\end{tabular}

